\title{
Solid Oxide Fuel Cell (SOFC); A New Approach of Energy Generation during the Pandemic COVID-19
}

\author{
Shammya Afroze ${ }^{1 *}$, Md Sumon Reza ${ }^{1}, Q_{\text {Quntin Cheok }}{ }^{1}$, Juntakan Taweekun ${ }^{2}$, \\ Abul K. Azad ${ }^{1}$
}

${ }^{1}$ Faculty of Integrated Technologies,

Universiti Brunei Darussalam, JalanTunku Link, Gadong, BE 1410, BRUNEI DARUSSALAM

${ }^{2}$ Department of Mechanical Engineering, Faculty of Engineering,

Prince of Songkla University, HatYai, Songkla, 90112, THAILAND

*Corresponding Author

DOI: https://doi.org/10.30880/ijie.2020.12.05.030

Received 00 Month 2000; Accepted 01 Month 2000; Available online 02 Month 2000

\begin{abstract}
The new coronavirus (COVID-19) has started spreading all over the world. Every infected is fighting to recover a little and every health worker is fighting to save a single life in this pandemic. There is no place for patients to stay in the hospital, health workers are given all possible services to save their lives. In this situation, uninterrupted power system is needed, which can be supplied by solid oxide fuel cells (SOFCs). Therefore, solid oxide fuel cells (SOFCs) are becoming attractive day by day with competing environmentally friendly energy sources due to high energy efficiency, low emission rate and comparatively low operating cost. The purpose of this work is to investigate how copper-doped perovskite electrode materials impact the performance of solid oxide fuel cells (SOFCs) to overcome such crucial times successfully. Different synthesis process of $\mathrm{Cu}$-based electrodes and analyzing electrochemical properties were investigated in this work. The evaluation was performed in terms of synthesis process, sintering temperature, lattice type and parameters, electrical conductivity, thermal expansion coefficients (TEC), polarization resistance, activation energy, and power density. In order to provide additional energy during this pandemic COVID-19, low-cost, highly performed, and durable materials are needed to make SOFC.
\end{abstract}

Keywords: COVID-19, Coronavirus, Solid Oxide Fuel Cell (SOFC), Perovskite, Cu-doped materials.

\section{Introduction}

In December 2019, the world faced with an unknown virus, the outbreak of which was in the city of Wuhan, China [1]. This mysterious virus is a new coronavirus which is caused due to severe desperate respiratory syndrome coronavirus 2 (SARS-CoV-2) with a pneumonia outbreak [2]. This deadly acute respiratory syndrome has been described by the World Health Organization (WHO) as the coronavirus 2019 (COVID-19) [3]. The virus has spread speedily in China at an increasing rate, and at one time, it spread to different parts of the world [4]. It can be said that now the whole world is affected by COVID-19. When this virus firs started spreading from human to human, a large number of patients were admitted into the hospital with a symptom of pneumonia feeling severe breathing absence resulting in acute respiratory failure and other serious impediments causing a lot of deaths [5]. WHO declares COVID19 as a pandemic on March 11 [6]. According to May 26, 2020, 5,609,999 patients have affected due to COVID-19 in 215 countries in the world, and the number of deaths is 348,253 worldwide (https://www.worldometers.info/coronavirus/). 


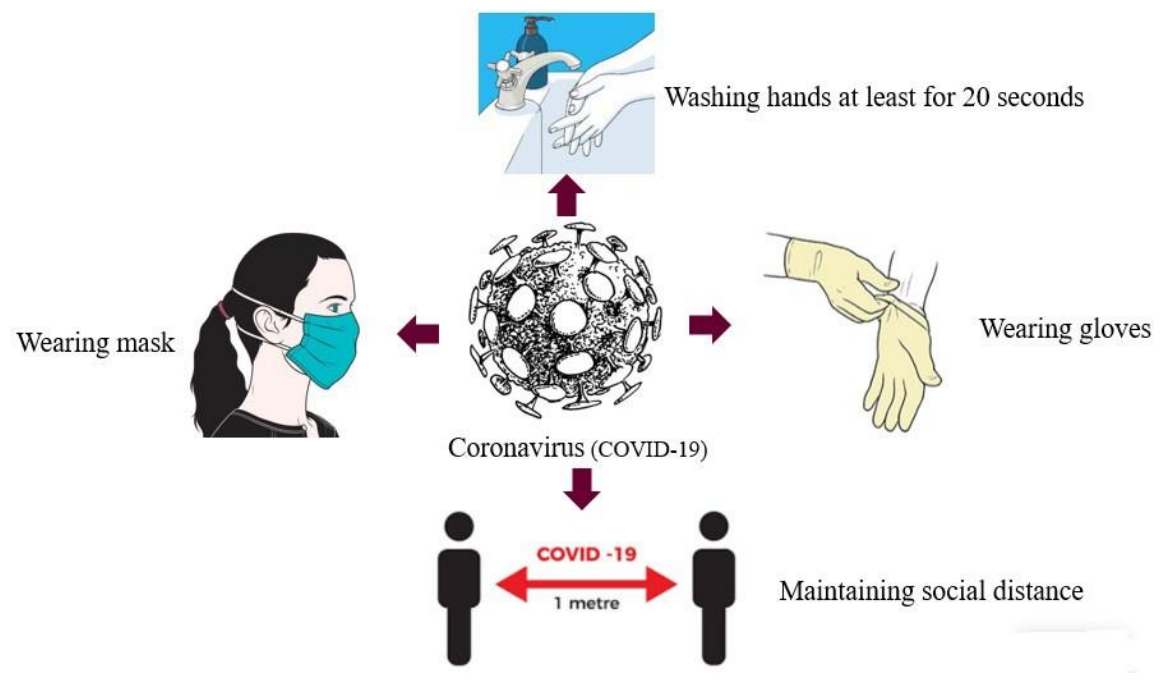

Fig. 1 - Protection and prevention from COVID-19

Table 1 - The five types of fuel cell devices and their respective parameters

\begin{tabular}{|c|c|c|c|c|c|}
\hline Categories & $\begin{array}{c}\text { Proton } \\
\text { exchange } \\
\text { membrane fuel } \\
\text { cell }\end{array}$ & $\begin{array}{l}\text { Molten } \\
\text { carbonate } \\
\text { fuel cell }\end{array}$ & $\begin{array}{l}\text { Phosphoric } \\
\text { acid fuel cell }\end{array}$ & $\begin{array}{l}\text { Solid oxide fuel } \\
\text { cell }\end{array}$ & Alkaline fuel cell \\
\hline Electrolyte & $\begin{array}{l}\text { Ion exchange } \\
\text { membrane }\end{array}$ & $\begin{array}{l}\text { Alkali } \\
\text { carbonates } \\
\text { mixture }\end{array}$ & $\begin{array}{l}\text { Phosphoric } \\
\text { acid }\end{array}$ & $\begin{array}{l}\text { Yttria-stabilized } \\
\text { zirconia }\end{array}$ & $\begin{array}{c}\text { An aqueous solution } \\
\text { of } \mathrm{KOH} \text { soaked in a } \\
\text { matrix }\end{array}$ \\
\hline $\begin{array}{l}\text { Operating } \\
\text { temperature }\end{array}$ & $80^{\circ} \mathrm{C}$ & $650^{\circ} \mathrm{C}$ & $200^{\circ} \mathrm{C}$ & $500^{\circ}-1000^{\circ} \mathrm{C}$ & $90^{\circ}-100^{\circ} \mathrm{C}$ \\
\hline Charge carrier & $\mathrm{H}^{+}$ & $\mathrm{CO}_{3}{ }^{=}$ & $\mathrm{H}^{+}$ & $\mathrm{O}^{=}$ & $\mathrm{OH}^{-}$ \\
\hline $\begin{array}{l}\text { Electrolyte } \\
\text { state }\end{array}$ & Solid & Liquid & Liquid & Solid & Alkaline \\
\hline Catalyst & Platinum & Nickel & Platinum & Ceramic & Nickel \\
\hline Fuel & Hydrogen & $\begin{array}{l}\text { Natural gas, } \\
\text { biogas, others }\end{array}$ & Natural gas & Natural gas & Hydrogen \\
\hline Advantages & $\begin{array}{l}\text { Load following } \\
\qquad \& \\
\text { low temperature }\end{array}$ & $\begin{array}{c}\text { High } \\
\text { efficiency, } \\
\text { scalable, fuel- } \\
\text { flexible \& } \\
\text { CHP }\end{array}$ & $\begin{array}{c}\text { Cogeneration } \\
- \text { combined } \\
\text { heat and } \\
\text { power }(\mathrm{CHP})\end{array}$ & $\begin{array}{l}\text { High efficiency, } \\
\text { load following } \\
\text { CHP }\end{array}$ & $\begin{array}{l}\text { Use of low-cost } \\
\text { materials, high } \\
\text { performance due to } \\
\text { alkaline electrolyte }\end{array}$ \\
\hline Efficiency $(\%)$ & 60 & $50-60$ & $40-45$ & $50-60$ & 60 \\
\hline $\begin{array}{l}\text { Power density } \\
\left(\mathrm{mW} / \mathrm{m}^{2}\right)\end{array}$ & $380-650$ & $150-260$ & $80-190$ & $100-2000$ & $80-100$ \\
\hline
\end{tabular}

This novel coronavirus is belonging to the family Coronaviridae (order Nidovirales) in the group of novel beta RNA coronavirus (size, 60-140 nm diameters) [7] causing cold, fever, with mild upper respiratory infections in the human body and few along with gastrointestinal symptoms (diarrhoea, vomiting, abdominal pain) [8],[9],[10]. At this time, the health workers cross the course through a terrible nightmare as they are trying to rescue the lives of every human being. Though there is no proven medicine or vaccine is invented yet and nobody knows when it will come [11]. Also, it spreads through human-to-human conduction, especially its nosogenic nature forces people to keep themselves isolated and maintain social distancing at 14 days [12],[13]. Protection and prevention are the only way to lessening the amounts of COVID-19 patients by wearing a face mask, using hand sanitizer, and maintaining physical distance [14] (Figure 1). Every day the rate of the amount of death is increasing as well as the number of patients. Hospitals, healthcare centers are struggling to cope with this colossal number of patients as every patient needs an artificial ventilator. They need an external power supply for maintaining the whole respiratory system with other electronic appliances to active all the time round the clock. 
This is a critical time to prioritize the supply of highly efficient and powerful energy to meet this additional demand [15]. The fuel cells can be the most suitable sources of renewable energy that can provide the extra power to mitigate the energy overflow. SOFC is one of the cleanest technologies for the hydrogen economy in next-generation with zero combustion [16]. The generation of electricity from directly converting the chemical energy that is stored as fuels into electrical energy is the main principle of a fuel cell. $\mathrm{CH}_{4}, \mathrm{H}_{2}$, methanol and light hydrocarbons are used as fuels in fuel cells [10]. In fuel cells, mechanical frictional losses are absent in the erosion process, which reduces emissions into the environment as well as increases fuel conversion efficacy, which is a great advantage of using fuel cells [19],[20]. Different types of fuel cells have been found so far, each of which has different qualities. Five major types of fuel cells with their advantages are tabulated in Table 1 [21].

Among all types of the fuel cells, SOFC gives relatively very high efficiency, fuel flexibility $\left(\mathrm{CH}_{4}, \mathrm{H}_{2}\right.$, biogas)

[7] and very low emissions as it is an alternate of energy sources, for instance, solar cells, wind energy, etc. [22],[23]. SOFC offers more than $60 \%$ efficiency with a clean environment [24]. Therefore, it can be used as one of the best sustainable energy sources. SOFC can be used as one of the best sustainable energy sources with an extensive power generation system. This device needs more useful materials for making it more usable.

Materials made with doped-copper have shown to be highly effective for SOFC. Copper-based perovskite materials have recently been used to produce electrode components in SOFCs. Excellent efficiency in reduced environments makes the $\mathrm{Cu}$-doped electrode very auspicious. It exhibits very high electrochemical performance at low operating temperatures. The strategies of improving the performance of SOFCs with doped copper materials are also discussed herewith in this article. The use of SOFC to meet this excess energy needs at this critical time is unavoidable. To make it more efficient and accessible to all, we need to use a material that is cheap, easy-going, and performs excellently. Among them, $\mathrm{Cu}$-doped content is incomparable.

\section{Solid Oxide Fuel Cells (SOFCs)}

Solid oxide fuel cell is now an attractive potential option due to its promised benefits in helping to keep people away from environmental pollution and providing clean and efficient power supply. SOFC is used as a highly-skilled energy conversion device that directly converts chemical energy to electrical energy by numerous electrochemical reactions [25],[26] from various gaseous fuels $\left(\mathrm{H}_{2}\right.$, hydrocarbon, $\mathrm{CH}_{4}, \mathrm{CO}$, biogas, etc.) with a very low emission in the environment. [27] SOFC can be forbearing to carbon monoxide $(\mathrm{CO})$ that can be oxidized to carbon dioxide $\left(\mathrm{CO}_{2}\right)$ [28]. By internal or external steam reforming, hydrogen gas can be formed from natural gas production. Research has stated that it is possible for any SOFC to burns dry hydrocarbon directly [29]. It can produce electricity around $100 \mathrm{~kW}$ which is greater than any other fuel cell. Owing to high operating temperatures, it has to face some limitations like high costs, slow start-up time, high degradation rates etc. SOFC is exceptionally well suited for power plants to provide a continuous stream of energy to the industry as well as to a whole city [30]. Currently, the performance of SOFC is improving year after year, thanks to advances in technology to develop SOFC materials, for example, SOFC can now easily be operated at high temperatures, typically $500-1000{ }^{\circ} \mathrm{C}[31]$.

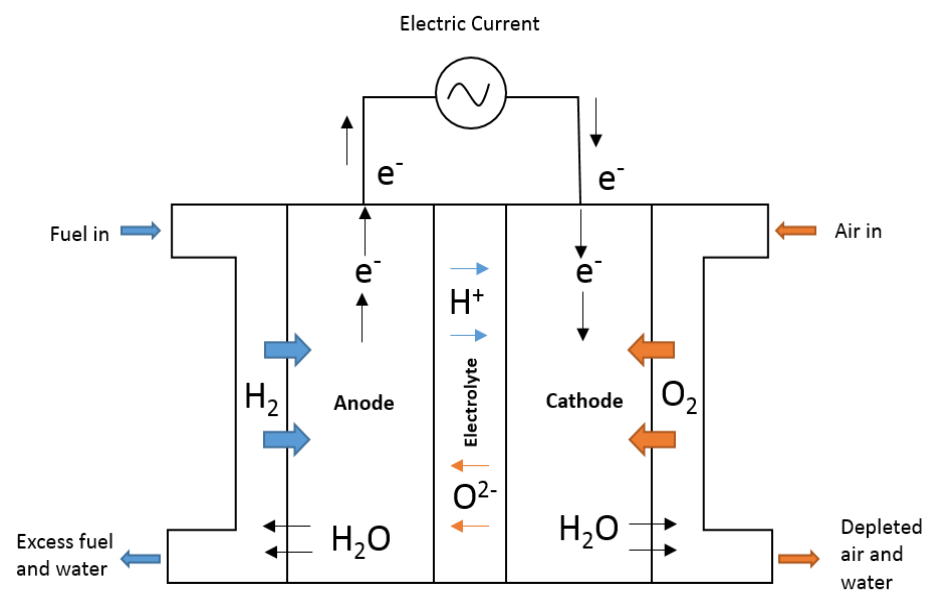

Fig. 2 - Schematic diagram of solid oxide fuel cell [32]

Generally, SOFC is made up of four layers: (i) anode, (ii) electrolyte, (iii) cathode, and (iv) interconnect. Out of the four segments, three layers (anode, electrolyte, and cathode) are made up of ceramics or solid materials and the fourt one (interconnect) is made up of metal. The air enters the cathode and the fuel enters the cathode. The oxygen in the air is reduced at the cathode by absorbing the electrons from it and forms as $\mathrm{O}^{-2}$. These oxygen ions diffuse through the electrolyte to the anode. Therefore, when the fuels enter the anode, absorb the oxygen with releasing heat and water $\left(\mathrm{H}_{2} \mathrm{O}\right)$ as well as two electrons. These two electrons will go to the external circuit where they generate power and again they enter into the cathode. These cycles will be repeated continuously to generate electricity and thus completing the whole SOFC circuit. A widely used electrolyte is yttria-stabilized zirconia (YSZ) [33] due to its high ionic 
conductivity, high chemical, and mechanical stability [34],[35]. Figure 2 depicts the working procedure of solid oxide fuel cells as an oxide ion-conducting electrolyte and proton-conducting electrolyte [36],[37]. The electrode halfreactions and overall cell reaction are shown in equations 1 to 3 [38].

At the cathode:

$$
\left(\frac{1}{2}\right) O_{2}+2 e^{-}=O^{2-}
$$

At the anode:

$$
\mathrm{H}_{2}+\mathrm{O}^{2-}=\mathrm{H}_{2} \mathrm{O}+2 e^{-}
$$

Overall:

$$
\mathrm{H}_{2}+\frac{1}{2} \mathrm{O}_{2}=\mathrm{H}_{2} \mathrm{O}
$$

Anode: The anode distributes the hydrogen gas evenly over its entire surface and conducts free electrons from the hydrogen molecule, which generates electricity in the SOFC circuit [39]. The anode plays a significant role in SOFC as it can convert catalysts directly into fuel [40]. Fuel flexibility should be the feature of an anode with increasing amounts of tolerating sulfur poisoning and carbon deposits [41]. It is also recommended for anodes to meet specific criteria, for instance, adequate electrical conductivity, thermal expansion compatibility, and high porosity [42]. These parameters are considered while selecting alternative anode materials for SOFCs. Nickel is preferred as anode material due to the fitness of the required components as described above. Nickel-YSZ (Ni-YSZ) was the most important discovery for the anode cermet for SOFCs [43]. This cermet meets all the criteria of material for the anodes, where it significantly increases fuel efficiency. At the present, attempts have been made with Copper-based cermets [44],[45].

Electrolyte: Electrolyte materials play a vital role as they have high ionic conductivity reacting between the electrodes for maximizing the efficiency of SOFCs, and thus completing the electrical circuit. The material should have sufficiently high ionic conductivity as well as low electronic conductivity to evade a short circuit across the cell. The performance of the electrolyte material depends on the relationship between the thicknesses and ohmic of the electrolyte and is proportionally linear [46]. Additionally, the material must be capable of forming a thin-dense film and also stable in both oxidizing and reducing the environment at the operating condition. YSZ demonstrates pure oxygen ionic conductivity. 8-mol\% Y doped $\mathrm{ZrO}_{2}$ is the usual electrolyte used for high-temperature solid oxide fuel cells due to its high ionic conductivity, stability and compatibility with electrode materials in the cell. But, YSZ is limited to hightemperature operation due to its poor ionic conductivity at temperatures below $800^{\circ} \mathrm{C}$. For SOFC, the operation temperature should be $500^{\circ} \mathrm{C}$, as it decreases the high-temperature materials requirements, and as well as it lowers the cost. As well, this improves the balance of plants so that the generation of heat may be used for further energy production, therefore maximizing the efficiency of the device. These factors have led to the development of several other materials for intermediate and low-temperature SOFC electrolytes. Currently, cubic fluorite oxides mainly doped zirconia is the most common electrolyte for SOFCs, though, the ionic conductivity is relatively low at high temperatures [47].

Cathode: The applications of the materials mainly depends on selecting the cathode for SOFC. These applications are the synthesis process of the desired materials, design of the electrochemical cell with its operating temperature, and the electrolyte materials that can be compatible with the electrode (both anode and cathode). Materials for SOFC cathodes are chosen that can optimize conductivity, thermal stability, and facilitating the oxygen reduction reaction. Cathode materials should have sufficiently high conductivities (typically $\mathrm{S} / \mathrm{cm}$ ) to enhance reactivity. The combination of mixed-ionic and electronic conductivity (MIEC) is required to increase the size of the triple-phase boundary (TPB), the sites of the cathode started the reaction where oxygen is depleted and transferred to the electrolyte. LSM (La0.8Sr0.2MnO3), provides excellent thermal expansion match with electrolytes and shows good performance at operating temperatures as the TPB sites are limited to the interface between cathode-electrolyte [48].

Solid oxide fuel cells are a striking alternative technology due to its promised benefits of providing clean and efficient energy to people away from environmental pollution. Its vast applications also attract researchers in the generation of portable power technology, such as mobile, laptop, etc. [49] and the broad sector of transport areas [50] 
The auxiliary power unit (APU) can be replaced with fuel cells to accommodate power generation on aircraft to decrease pollutants and noise emissions for new and cleaner atmosphere [51]. The aviation industry can think about the future use of fuel cells in aircraft for civil aircraft applications. Another primary application of SOFC is a micro-CHP system combined with SOFC to generate electricity in heating houses and residential areas. The residential heating has been recognized as a challenging sector in the fuel cell sector to decarbonize. Solid oxide fuel cells, combined with microCHP units, can drastically reduce associated emissions [52],[53]. All of these versatile applications of SOFCs are environmentally friendly, i.e., they maintain a clean and green environment. Therefore, SOFC needs those materials that are cost-effective and have a high conductivity as well as high performance to make it more effective.

\section{Materials for SOFC}

Already many materials have been used as SOFC electrodes, but the main problem of commercialization is to steadiness the reliability and durability of these materials at low cost. Among all the materials, perovskite materials are the well-desired candidate for SOFC electrode nowadays as it exhibits significant properties such as attractive ionic and catalytic properties [54],[55], superconductivity [56], piezoelectric [57], pyroelectrical properties and so on. There are some challenges that this technology will be drawn in the upcoming discussion.

The perovskite structure is one of the oldest, most studied configurations in solid-state inorganic chemistry. It has since become a generic name to describe the family of materials comprising this structure. Perovskites have a formula $\mathrm{ABX}_{3}$, where $\mathrm{A}$ and $\mathrm{B}$ represent metal cations, and $\mathrm{X}$ is a charge balancing anion, typically oxygen. These perovskite oxides are therefore described by formula $\mathrm{ABO}_{3}$ (Figure 3). The A-site cations usually are rare earth, alkali, or alkali earth elements, and the transition metals are conventionally in the B site. The B-site cation is the coordination of 6 oxygen atoms in the form of a corner-sharing octahedral [58].

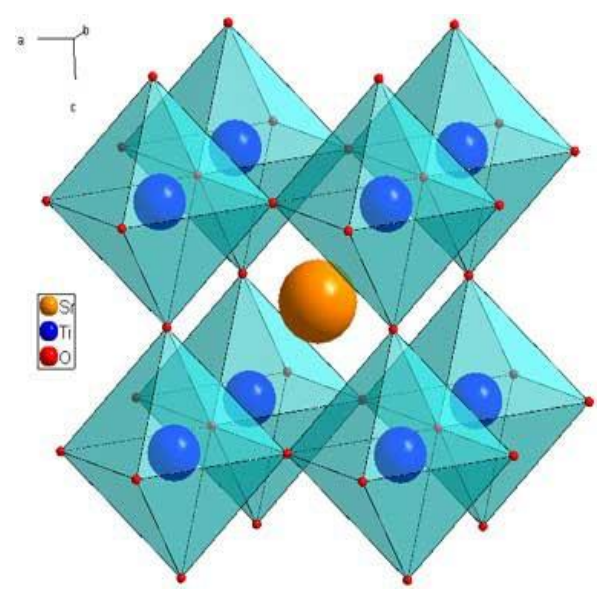

Fig. 3 - A general cubic structure of the perovskite oxides, $\mathrm{ABO}_{3}$

The perovskite structure is a combination of various metal ions. The prediction of the crystal parameters is an important aspect when developing and synthesizing new perovskite materials. Therefore extensive work has been done to understand the effect of the size of cation on the structure. The majority of perovskite structures can be qualitatively predicted using the Goldshmidt Tolerance Factor. Goldschmidt's tolerance factor relates the ionic radii of the A and B cations to the lattice parameters of the perovskite unit cell [59]. The tolerance factor, $t$, is calculated from trigonometry, utilizing a ratio between the bond lengths, A-O, and B-O.

$$
t=\frac{r_{A}+r_{0}}{\sqrt{2}\left(r_{B}+r_{0}\right)}
$$

Where $r_{A}, r_{B}$, and $r_{0}$ are the ionic radii of $\mathrm{A}, \mathrm{B}$, and $\mathrm{O}$, respectively.

In the perovskite structure, the anions (oxygen) separate both the A and B cations. This means that the lattice constant, $a$, can be determined by the sum of the ionic diameters of oxygen and the B-cation. The relationship between the lattice constant, $a$, and the A-site cation is more complex due to their relative positions in the unit cell. Also, in the ideal cubic structure, the contact distance between the A and B site cations are equal to each other. Since most elements do not satisfy the requirements for the ideal arrangement, the tolerance factor, $t$, is included and is an A-O to B-O bond length ratio in the perovskite. When the tolerance factor, $t>1 \rightarrow$ the size of A-site cations is massively big to fit into their interstices $\rightarrow$ Hexagonal structure, $t \sim 0.9-1.0 \rightarrow$ A-site, and B-site cations fit precisely into their allotted site 
(Ideal condition) $\rightarrow$ Cubic structure, $t=0.75-0.9 \rightarrow$ A-site cations are too lesser to fit into their assigned sites $\rightarrow$ Orthorhombic and Rhombohedral structure, and $t<0.71 \rightarrow$ Both A-site cations and B-site cations are of the same size $\rightarrow$ Correndum and Ilmenite structures.

Table 2 - Composition, synthetic method, sintering temperature, lattice type and parameters of $\mathrm{Cu}$-based perovskite electrodes

\begin{tabular}{|c|c|c|c|c|c|c|c|c|c|}
\hline Composition & $\begin{array}{l}\text { Electrod } \\
\text { e type }\end{array}$ & $\begin{array}{l}\text { Synthesis } \\
\text { method }\end{array}$ & $\begin{array}{c}\text { Sinterin } \\
\text { g temp. } \\
{\left[{ }^{\circ} \mathbf{C}\right]}\end{array}$ & $\begin{array}{l}\text { Lattice } \\
\text { type }\end{array}$ & $\begin{array}{l}\text { Space } \\
\text { group }\end{array}$ & $\mathbf{a}[\mathbf{A}]$ & $\mathbf{b}[\AA]$ & c [Å] & Ref. \\
\hline $\begin{array}{l}\mathrm{La}_{0.6 .} \mathrm{Sr}_{0.4} \mathrm{Fe}_{0.8} \\
\mathrm{Cu}_{0.2 .} \mathrm{O}_{3-\delta}\end{array}$ & Cathode & $\begin{array}{l}\text { EDTA-citrate } \\
\text { complexation } \\
\text { process }\end{array}$ & $1000^{\circ} \mathrm{C}$ & - & - & - & - & - & [60] \\
\hline $\begin{array}{l}\mathrm{LaCo}_{0.5} \mathrm{Cu}_{0.5} \\
\mathrm{O}_{3-\delta}\end{array}$ & Cathode & Citrate route & $600^{\circ} \mathrm{C}$ & - & - & - & - & - & [61] \\
\hline $\begin{array}{l}\mathrm{SrFe}_{0.7} \mathrm{Cu}_{0.2} \mathrm{Ti} \\
0.1 \mathrm{O}_{3-\delta}\end{array}$ & Electrode & Sol-gel & $1300{ }^{\circ} \mathrm{C}$ & Cubic & $P m-3 m$ & 3.8833 & 3.8833 & 3.8833 & [62] \\
\hline $\begin{array}{l}\mathrm{Bi}_{0.5} \mathrm{Sr}_{0.5} \mathrm{Fe}_{0.8} \\
\mathrm{Cu}_{0.2} \mathrm{O}_{3-\delta}\end{array}$ & Cathode & Solid-state & $1400{ }^{\circ} \mathrm{C}$ & Cubic & $P m-3 m$ & 3.9326 & 3.9326 & 3.9326 & [63] \\
\hline $\begin{array}{l}\mathrm{SrFe}_{0.8} \mathrm{Cu}_{0.1} \mathrm{~N} \\
\mathrm{~b}_{0.1} \mathrm{O}_{3-\delta}\end{array}$ & & Sol-gel & $1450{ }^{\circ} \mathrm{C}$ & Cubic & $P m-3 m$ & & & & [64] \\
\hline $\begin{array}{l}\mathrm{Pr}_{0.7} \mathrm{Sr}_{0.3} \mathrm{Co}_{1-} \\
\mathrm{Cu}_{y} \mathrm{O}_{3-\delta}(y= \\
0.05-0.4)\end{array}$ & Cathode & Sol-gel & $950^{\circ} \mathrm{C}$ & $\begin{array}{l}\text { Orthorh } \\
\text { ombic }\end{array}$ & - & - & - & - & [65] \\
\hline $\begin{array}{l}\mathrm{Nd}_{0.6} \mathrm{Sr}_{0.4} \mathrm{Co}_{0} \\
{ }_{8} \mathrm{M}_{0.2} \mathrm{O}_{3-\delta}\end{array}$ & Cathode & Solid-state & $1300^{\circ} \mathrm{C}$ & $\begin{array}{l}\text { Orthorh } \\
\text { ombic }\end{array}$ & - & 5.3777 & 5.3861 & 7.6108 & [66] \\
\hline $\begin{array}{l}\mathrm{La}_{0.75} \mathrm{Sr}_{0.25} \mathrm{Cu} \\
\mathrm{O}_{2.5-\delta}\end{array}$ & Cathode & $\begin{array}{l}\text { Conventional } \\
\text { ceramic } \\
\text { process }\end{array}$ & $950^{\circ} \mathrm{C}$ & - & - & - & - & - & [67] \\
\hline $\begin{array}{l}\mathrm{Sm}_{0.5} \mathrm{Sr}_{0.5} \mathrm{Fe}_{0.8} \\
\mathrm{Cu}_{0.2 \mathrm{O}-\delta}\end{array}$ & Cathode & $\begin{array}{l}\text { Autoignition } \\
\text { process }\end{array}$ & $950^{\circ} \mathrm{C}$ & Cubic & $P m-3 m$ & & & & [68] \\
\hline $\begin{array}{l}\mathrm{Ba}_{0.5} \mathrm{Sr}_{0.5} \mathrm{Fe}_{0.8} \\
\mathrm{Cu}_{0.2} \mathrm{O}_{3-\delta}\end{array}$ & Cathode & $\begin{array}{l}\text { Auto ignition } \\
\text { process }\end{array}$ & $950^{\circ} \mathrm{C}$ & Cubic & $P m-3 m$ & - & - & - & [69] \\
\hline $\begin{array}{l}\mathrm{La}_{0.6} \mathrm{Sr}_{0.4} \mathrm{Co}_{0.2} \\
\mathrm{Fe}_{0.7 .7} \mathrm{Cu}_{0.1} \mathrm{O}_{3-}\end{array}$ & Cathode & Solid-state & $950{ }^{\circ} \mathrm{C}$ & $\begin{array}{l}\text { Rhombo } \\
\text { hedral }\end{array}$ & $R 3 c$ & 5.4544 & 5.4544 & 2.4559 & [70] \\
\hline $\begin{array}{l}\delta \\
\mathrm{La}_{0.6} \mathrm{Sr}_{0.4} \mathrm{Co}_{0.1} \\
\mathrm{Fe}_{0.8} \mathrm{Cu}_{0.1} \mathrm{O}_{3-} \\
\delta\end{array}$ & Cathode & Solid-state & $950^{\circ} \mathrm{C}$ & $\begin{array}{c}\text { Rhombo } \\
\text { hedral }\end{array}$ & $R 3 c$ & 5.4692 & 5.4692 & 2.4421 & [70] \\
\hline
\end{tabular}

The value of $t$ is calculated and used to determine the stability of the perovskite structure qualitatively. Values between 0.9-1.0 are said to be the ideal case, giving rise to cubic perovskite structures where the $\mathrm{A}$ and $\mathrm{B}$ cation radii match perfectly. If a small A-site metal cation is used, the octahedral of the B-site tends to tilt to adjust the small A-site cation radius and the tolerance factor decreases. Generally, if a combination of A and B metals gives a $t$ value of 0.8 1.0 , the perovskite structure will be obtained in some form.

Most of the elements from the periodic table can be accommodated in the perovskite structure, leading to a wide range of possible material combinations. This ability to include most elements allows one to easily tailor the material properties for specific applications by doping at the A and/or B site. Elemental doping has been shown to enhance many favorable properties such as electrical conductivity, mechanical strength, magnetism, catalytic reactivity, and surface area, etc. [35]. The dopant is typically chosen to enhance a certain property of the material specifically. The dopant can inordinately influence the electronic properties depending on the material nature and the band structure. As well, dopants of variable oxidation states are conventionally used to introduce oxygen vacancies within the perovskite. The majority of perovskites fall into three subcategories depending on the relative oxidation states of the A and B site cations. However, the perovskite structure is highly tolerant of oxide vacancies and can, therefore, accommodate elements of various oxidation states in either the A and/or B sites. For example, a perovskite with trivalent A and B site cations would have a general formula $\mathrm{A}^{+3} \mathrm{~B}^{+3} \mathrm{O}_{3}$. By substituting a divalent metal for the $\mathrm{B}$ site cation, the perovskite structure necessarily loses oxygen in the form of vacancies to obey charge neutrality. This leads to the formation of $\mathrm{A}^{+3} \mathrm{~B}^{+3}{ }_{1-\mathrm{x}} \mathrm{B}^{+2}{ }_{\mathrm{x}} \mathrm{O}_{3-\delta}$, where $\mathrm{x}$ equals the fraction of dopant and $\delta$ is the degree of oxygen vacancies. The structure can be further modified by additional doping at the $\mathrm{A}$ site, leading, for example, to a formula $\mathrm{A}^{+3}{ }_{1-\mathrm{x}} \mathrm{A}^{+2}{ }_{\mathrm{x}} \mathrm{B}^{+3}{ }_{1-\mathrm{y}} \mathrm{B}^{+2} \mathrm{O}_{3-\delta}$. The 
perovskite system can accommodate a substantial level of dopants and become quite complicated.

\section{Development of Cu-doped materials}

The authors will mainly fixate on several copper doped electrode materials that have already been used in SOFC in this section, and their sintering method, lattice type, space group, and lattice constants have been reported thoroughly. Doping strategy and electrochemical performance will be mainly discussed in this review.

ASR (area-specific resistance), $\mathrm{E}_{\mathrm{a}}$ (activation energy), electrical conductivity, and TEC (thermal expansion coefficient) will be discussed to compare the investigated electrode materials in SOFC. The significant physical, chemical and electrochemical constraints are reported in the following tables for some of the compounds. The values of

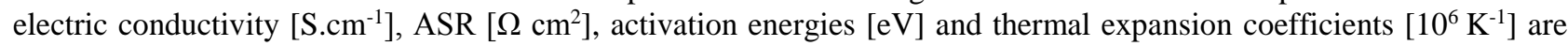
obtained here by reviewing various studies. The electrocatalytic performance of the electrode materials generally depends on doping both A- and B-site cations. To evaluate and forecast the durability of the perovskite-type electrode materials, and how suitable they are with other SOFCs components during operation at a temperature, the data are required. The preparation method, sintering temperature, space group, and lattice parameters for the same compounds were tabulated in Table 2.

\section{Enhancement of material performance}

TEC is an essential parameter for SOFCs. Ideally, all materials used in SOFCs should have the same TEC values. But thermomechanical stress occurs due to their mismatch configuration. Also, differences in TEC affect the lifetime of the cell as different cell layers will have varying thickness [71]. In addition to the thermal properties, the electrochemical performance of electrodes in SOFC is also essential for determining the likelihood of new, improved materials. Over potential, overvoltage, or loss can be caused due to the polarization resistance. These polarizations are evident in a characteristic SOFC curve and is very crucial to determining electrode performance. SOFC needs a porous anode supported cell for lower polarization resistance [72]. The polarization of cathode usually occurs when the value of the potential is less than the likely open-circuit voltage. This circumstance is also known as corrosion of the possible. It is essential to separate the effect of local electrochemistry of the triple-phase boundary (TPB) and that of morphological structure for simulating the transport characteristics of SOFC electrodes [73].

Cathode/electrolyte/cathode arrangement or anode/electrolyte/anode arrangement is mainly built to form a symmetrical SOFC cell. Electrochemical impedance spectroscopy (EIS) analysis is used to study these balanced cells. The resistance at the grain boundary of the electrolyte gives the impedance value, which is attained at the high-frequency part. After that, the equivalent circuit is spawned from the Nyquist plot of the arcs. An equivalent circuit is shown in Figure 4 to analyze the symmetrical cell. There is four resistance in the circuit, Four resistors comprise the circuit, of which there is the ohmic resistance, Rs, and the sum of remaining resistances is the polarization resistance of the electrode, $R_{p}$. Electrical conductivity, ASR, $\mathrm{E}_{\mathrm{a}}$, TEC, and power density of $\mathrm{Cu}$-based compounds, which are most important for SOFC, were addressed in Table 3.

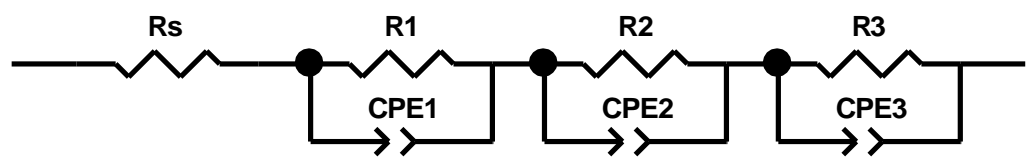

Fig. 4 - Equivalent circuit for symmetrical cells

From literature, the $\mathrm{R}_{\mathrm{p}}$ value obtained for copper doped electrodes, such as LSFCO, LCCO, BSFCO, and SFCNO, is respectively 0.306 to 0.300 . In Table 3 , the difference in $R_{p}$ was recorded mainly due to the types of materials and operating temperature of the cells. The processing method of the electrode powders determines the particle size. An increase in particle size leads to a decreasing in surface area of the electrode, which then yields higher resistance and poor conductivity in the component [74],[75]. All the factors mentioned here need to be considered before producing the copper doped electrodes. 
Table 3 - Composition, electrical conductivity s, ASR, activation energy, and TEC of Cu-based perovskite electrodes

\begin{tabular}{|c|c|c|c|c|c|c|c|c|}
\hline Composition & o at 600 & o at 700 & ASR at & $\mathbf{E}_{\mathbf{a}}$ & TEC & Power & Power & Ref. \\
\hline & $\begin{array}{l}{ }^{\circ} \mathrm{C} \\
{\left[\mathrm{S} . \mathrm{cm}^{-1}\right]}\end{array}$ & $\begin{array}{l}{ }^{\circ} \mathbf{C} \\
{[\text { S.cm }}\end{array}$ & $\begin{array}{l}70{ }^{\circ} \mathrm{C} \\
{\left[\Omega \mathrm{cm}^{2}\right]}\end{array}$ & {$[\mathrm{eV}]$} & $\begin{array}{l}{\left[10^{6}\right.} \\
\left.\mathrm{K}^{-1}\right]\end{array}$ & $\begin{array}{c}\text { density at } \\
700{ }^{\circ} \mathbf{C} \\
{\left[\mathrm{mWCm}^{-2}\right]}\end{array}$ & $\begin{array}{c}\text { density at } \\
800{ }^{\circ} \mathrm{C} \\
{\left[\mathrm{mWcm}^{-2}\right]}\end{array}$ & \\
\hline $\mathrm{La}_{0.6} \mathrm{Sr}_{0.4} \mathrm{Fe}_{0.8} \mathrm{Cu}_{0.2} \mathrm{O}_{3-\delta}$ & 190.000 & - & 0.306 & - & $\begin{array}{c}14.60 \\
0\end{array}$ & 291.000 & 530.000 & [76] \\
\hline $\mathrm{LaCo}_{0.5} \mathrm{Cu}_{0.5} \mathrm{O}_{3-\delta}$ & - & - & $<0.100$ & - & - & - & - & [61] \\
\hline $\mathrm{SrFe}_{0.7} \mathrm{Cu}_{0.2} \mathrm{Ti}_{0.1} \mathrm{O}_{3-\delta}$ & - & 10.000 & - & - & - & - & - & [62] \\
\hline $\mathrm{Bi}_{0.5} \mathrm{Sr}_{0.5} \mathrm{Fe}_{0.8} \mathrm{Cu}_{0.2} \mathrm{O}_{3-\delta}$ & - & - & 0.130 & - & $\begin{array}{c}13.10 \\
0\end{array}$ & 290.000 & - & [63] \\
\hline $\mathrm{SrFe}_{0.8} \mathrm{Cu}_{0.1} \mathrm{Nb}_{0.1} \mathrm{O}_{3-\delta}$ & - & $\begin{array}{c}30.000- \\
60.000\end{array}$ & 0.300 & - & - & 372.000 & - & [64] \\
\hline $\mathrm{Pr}_{0.7} \mathrm{Sr}_{0.3} \mathrm{Co}_{0.9} \mathrm{Cu}_{0.1} \mathrm{O}_{3-\delta}$ & - & - & - & 0.089 & - & 406.000 & - & [65] \\
\hline $\mathrm{La}_{0.75} \mathrm{Sr}_{0.25} \mathrm{CuO}_{2.5-\delta}$ & - & - & 1.210 & - & - & 0.280 & 0.650 & [67] \\
\hline $\mathrm{Sm}_{0.5} \mathrm{Sr}_{0.5} \mathrm{Fe}_{0.8} \mathrm{Cu}_{0.2} \mathrm{O}_{3-\delta}$ & 82.000 & - & 0.085 & - & $\begin{array}{c}12.00 \\
0\end{array}$ & 808.000 & - & [68] \\
\hline $\mathrm{Ba}_{0.5} \mathrm{Sr}_{0.5} \mathrm{Fe}_{0.8} \mathrm{Cu}_{0.2} \mathrm{O}_{3-\delta}$ & 57.000 & - & 0.137 & - & - & 718.000 & - & [69] \\
\hline $\begin{array}{l}\mathrm{La}_{0.6} \mathrm{Sr}_{0.4} \mathrm{Co}_{0.2} \mathrm{Fe}_{0.7} \mathrm{Cu}_{0.1} \mathrm{O}_{3} \\
-\delta\end{array}$ & - & - & - & - & $\begin{array}{c}17.60 \\
0\end{array}$ & - & - & [70] \\
\hline$\underset{-\delta}{\mathrm{La}_{0.6} \mathrm{Sr}_{0.4} \mathrm{Co}_{0.1} \mathrm{Fe}_{0.8} \mathrm{Cu}_{0.1} \mathrm{O}_{3}}$ & - & - & - & - & $\begin{array}{c}12.20 \\
0\end{array}$ & - & - & [70] \\
\hline
\end{tabular}

From Table 3, it is shown clearly that $\mathrm{Sm}_{0.5} \mathrm{Sr}_{0.5} \mathrm{Fe}_{0.8} \mathrm{Cu}_{0.2} \mathrm{O}_{3-\delta}$, the SOFC cathode, displays excellent performance $\left(0.808 \mathrm{Wcm}^{-2}\right.$ at $\left.700{ }^{\circ} \mathrm{C}\right)$ [68]. This sample was prepared through the auto-ignition process and the sintering temperature was $950{ }^{\circ} \mathrm{C}$. Cell performance also depends on the porosity of the prepared materials [77]. The optimal level of porosity for electrodes in SOFC is around 40\% [78]. Figure 5 describes that the cell membrane is completely impenetrable, and the grains are uniformly distributed resulting in high power density values. The porous electrode also affects the performance of SOFCs [79],[80] due to their triple-phase-boundaries (TPB), which may points or lines where pores, electrolyte, and catalyst meet [81].
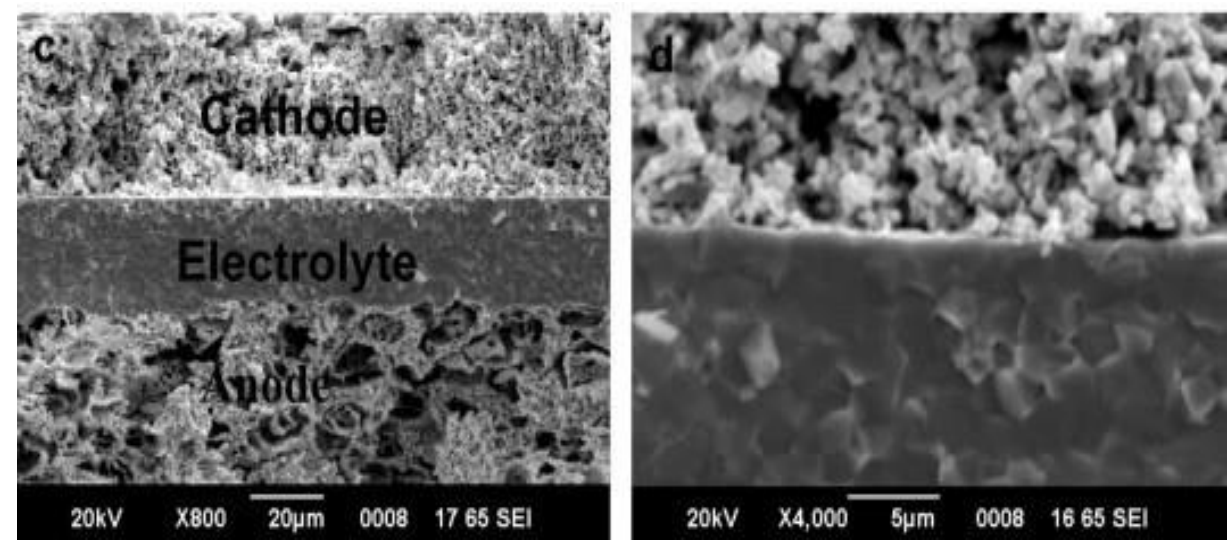

Fig. 5 - SEM micrographs of electrode materials and the symmetric cell [68]

\section{Effect of SOFC on prevention of COVID-19}

SOFC is such an external energy source from which the generated energy is used according to demand and transfers excess electricity to the grid. Every year, the amount of electricity bills that have to be paid is very high. To mitigate this high billing payment issue and excess energy demand, we need to focus on external power generation. With the help of SOFC, a microgrid system is already developed to capable of powering a hospital with providing constant power supply by the company, Bloom Energy, in the USA to accommodate the patient overflow [82]. Also, the micro-CHP systems combined with SOFC can be used during this pandemic COVID-19 to the individual residence and hospitals [83],[84].

Concerning to commercialization of SOFC, the first thing that comes to mind is its new market value with high performance [85]. A decrease in the overall cost of the cell leads to an increase in demand to adopt it [86],[87]. 
Recently, researchers show their keen interest in developing suitable and low-cost materials, especially electrodes, to the commercialization of SOFC. Therefore, their primary aim to overview different perovskite-type materials doped with copper, which are prospective for electrode materials in SOFCs, as copper is a much cheaper material in the periodic table and has availability on earth.

\section{Conclusion}

It is an incredible battle - today, the whole world is now continually fighting to protect itself from the novel coronavirus, COVID-19. Every moment is spent amid an unknown fear. As no drugs or vaccine is discovered so far, maintaining social distance is the only antidote. Despite being on the verge of death, health workers are constantly serving patients. As the number of patients is increasing day by day, a continuous power supply is needed to ensure that all their treatments are on time. SOFC is the only source of energy that can provide uninterrupted power and exquisite quality materials are required to operate this SOFC properly. The development of copper-doped electrodes in SOFC can give good potential. In addition to reducing TEC differences between electrode and electrolyte, acceptable polarization resistance is seen in copper doped electrodes in EIS analysis. The use of SOFC to fight against this pandemic is unavoidable. SOFC made of suitable quality materials can provide uninterrupted power which is what we need right now. It is not just the time of this pandemic but any other normal time we can use this continuous power supply of SOFC.

\section{Acknowledgment}

The author Shammya Afroze is gratefully acknowledged to the award of UBD Graduate Scholarship (UGS) by Universiti Brunei Darussalam.

\section{Reference}

[1] Lu, H., Stratton, C. W., \& Tang, Y. (2020). Outbreak of pneumonia of unknown etiology in Wuhan, China: The mystery and the miracle. Journal of Medical Virology, 92(4), 401-402.

[2] Gorbalenya, A. E., Baker, S. C., Baric, R. S., de Groot, R. J., Drosten, C., Gulyaeva, A. A., ... Ziebuhr, J. (2020). The species Severe acute respiratory syndrome-related coronavirus: classifying 2019-nCoV and naming it SARS-CoV-2. Nature Microbiology, 5(4), 536-544.

[3] Peng, P. W. H., Ho, P. L., \& Hota, S. S. (2020, May 1). Outbreak of a new coronavirus: what anaesthetists should know. British Journal of Anaesthesia. Elsevier Ltd.

[4] Chen, N., Zhou, M., Dong, X., Qu, J., Gong, F., Han, Y., ... Zhang, L. (2020). Epidemiological and clinical characteristics of 99 cases of 2019 novel coronavirus pneumonia in Wuhan, China: a descriptive study. The Lancet, 395(10223), 507-513.

[5] Xiang, N., Havers, F., Chen, T., Song, Y., Tu, W., Li, L., .. Feng, Z. (2013). Use of national pneumonia surveillance to describe influenza A(H7N9) virus epidemiology, China, 2004-2013. Emerging Infectious Diseases, 19(11), 1784-1790.

[6] WHO Director-General's opening remarks at the media briefing on COVID-19 - 11 March 2020. (n.d.). Retrieved May 9, 2020, from https://www.who.int/dg/speeches/detail/who-director-general-s-opening-remarksat-the-media-briefing-on-covid-19 11-march-2020

[7] Weiss, S. R., \& Navas-Martin, S. (2005). Coronavirus Pathogenesis and the Emerging Pathogen Severe Acute Respiratory Syndrome Coronavirus. Microbiology and Molecular Biology Reviews, 69(4), 635-664.

[8] Tay, M. Z., Poh, C. M., Rénia, L., MacAry, P. A., \& Ng, L. F. P. (2020). The trinity of COVID-19: immunity, inflammation and intervention. Nature Reviews Immunology, 1-12.

[9] Li, Q., Guan, X., Wu, P., Wang, X., Zhou, L., Tong, Y., ... Feng, Z. (2020). Early Transmission Dynamics in Wuhan, China, of Novel Coronavirus-Infected Pneumonia. New England Journal of Medicine, 382(13), 11991207.

[10] Li, Q., Guan, X., Wu, P., Wang, X., Zhou, L., Tong, Y., ... Feng, Z. (2020). Early Transmission Dynamics in Wuhan, China, of Novel Coronavirus-Infected Pneumonia. New England Journal of Medicine, 382(13), 11991207.

[11] Oxford COVID-19 vaccine begins human trial stage — NDM Research Building. (n.d.). Retrieved May 10, 2020, from https://www.ndmrb.ox.ac.uk/about/news/oxford-covid-19-vaccine-begins-human-trial-stage

[12] Zaki, A. M., Van Boheemen, S., Bestebroer, T. M., Osterhaus, A. D. M. E., \& Fouchier, R. A. M. (2012). Isolation of a novel coronavirus from a man with pneumonia in Saudi Arabia. New England Journal of Medicine, 367(19), 1814-1820.

[13] Parmet, W. E., \& Sinha, M. S. (2020, April 9). Covid-19 - The law and limits of quarantine. New England Journal of Medicine. Massachussetts Medical Society.

[14] Chang, D., Xu, H., Rebaza, A., Sharma, L., \& Dela Cruz, C. S. (2020). Protecting health-care workers from subclinical coronavirus infection. The Lancet Respiratory Medicine, 8(3), e13. 
[15] Gielen, D., Boshell, F., Saygin, D., Bazilian, M. D., Wagner, N., \& Gorini, R. (2019). The role of renewable energy in the global energy transformation. Energy Strategy Reviews, 24, 38-50.

[16] Cascos, V., Troncoso, L., Alonso, J. A., \& Fernández-Díaz, M. T. (2017). Design of new Ga-doped SrMoO3 perovskites performing as anode materials in SOFC. Renewable Energy, 111, 476-483.

[17] Snyder, G. J., \& Haile, S. M. (2004). Fuel cell materials and components. In Advanced Materials for Energy Conversion II (pp. 33-41).

[18] Abdalla, A. M., Hossain, S., Azad, A. T., Petra, P. M. I., Begum, F., Eriksson, S. G., \& Azad, A. K. (2018). Nanomaterials for solid oxide fuel cells: A review. Renewable and Sustainable Energy Reviews, 82, 353-368.

[19] Babaei, A., Zhang, L., Tan, S. L., \& Jiang, S. P. (2010). Pd-promoted (La,Ca)(Cr,Mn)O3/GDC anode for hydrogen and methane oxidation reactions of solid oxide fuel cells. Solid State Ionics, 181(25-26), 1221-1228.

[20] Vignarooban, K., Lin, J., Arvay, A., Kolli, S., Kruusenberg, I., Tammeveski, K., ... Kannan, A. M. (2015). Nano-electrocatalyst materials for low temperature fuel cells: A review. Chinese Journal of Catalysis, 36(4), 458-472.

[21] Raduwan, N. F., Muchtar, A., Somalu, M. R., Baharuddin, N. A., \& Muhammed Ali, S. A. (2018). Challenges in fabricating solid oxide fuel cell stacks for portable applications: A short review. International Journal of Integrated Engineering, 10(5), 80-86.

[22] Hossain, S., Abdalla, A. M., Jamain, S. N. B., Zaini, J. H., \& Azad, A. K. (2017). A review on proton conducting electrolytes for clean energy and intermediate temperature-solid oxide fuel cells. Renewable and Sustainable Energy Reviews, 79, 750-764.

[23] Abdalla, A. M., Hossain, S., Zhou, J., Petra, P. M. I., Erikson, S., Savaniu, C. D., ... Azad, A. K. (2017). $\mathrm{NdBaMn} 2 \mathrm{O} 5+\delta$ layered perovskite as an active cathode material for solid oxide fuel cells. Ceramics International, 43(17), 15932-15938.

[24] Stambouli, A. B., Traversa, E., \& Stambouli, A. (2002). Solid oxide fuel cells (SOFCs): a review of an environmentally clean and efficient source of energy. Renewable and Sustainable Energy Reviews (Vol. 6). Retrieved from www.elsevier.com/locate/rser

[25] Ud Din, Z., \& Zainal, Z. A. (2017). The fate of SOFC anodes under biomass producer gas contaminants. Renewable and Sustainable Energy Reviews. Elsevier Ltd.

[26] Aman, N. A. M. N., Muchtar, A., Somalu, M. R., Rosli, M. I., Baharuddin, N. A., \& Kalib, N. S. (2018). A short review on the modeling of solid-oxide fuel cells by using computational fluid dynamics: Assumptions and boundary conditions. International Journal of Integrated Engineering, 10(5), 87-92.

[27] Afroze, S., Karim, A. H., Cheok, Q., Eriksson, S., \& Azad, A. K. (2019). Latest development of double perovskite electrode materials for solid oxide fuel cells : a review. Frontiers in Energy, 13(4), 770-779.

[28] Tao, S., \& Irvine, J. T. S. (2003). A redox-stable efficient anode for solid-oxide fuel cells. Nature materials, 2(5), 320-323.

[29] Park, S., Craciun, R., Vohs, J. M., \& Gorte, R. J. (1999). Direct Oxidation of Hydrocarbons in a Solid Oxide Fuel Cell: I. Methane Oxidation. Journal of The Electrochemical Society, 146(10), 3603.

[30] Da Han, D., Liu, X., Zeng, F., Qian, J., Wu, T., \& Zhan, Z. (2012). A micro-nano porous oxide hybrid for efficient oxygen reduction in reduced-temperature solid oxide fuel cells. Scientific Reports, 2(1), 462.

[31] Shao, Z., \& Haile, S. M. (2004). A high-performance cathode for the next generation of solid-oxide fuel cells. Nature, 431(7005), 170-173.

[32] Shruti Yadav, Mukund Kumar Singh, K. S. (2015). Modelling of Solid Oxide Fuel Cell - A Review. International Journal of Scientific \& Engineering Research, 6(4), 834.

[33] Mat, Z. A., Nadaraja, S. K., Zakaria, Z., Hassan, S. H. A., Kar, Y. B., Tan, C. Y., \& Somalu, M. R. (2019). Fabrication and characterization of YSZ/ScSZ bilayer electrolyte via Cold- Isostatic Pressing (CIP) method for intermediate temperature-solid oxide fuel cell (IT-SOFC) application. International Journal of Integrated Engineering, 11(7), 201-208.

[34] High-temperature Solid Oxide Fuel Cells: Fundamentals, Design and Applications - Google Books. (n.d.). Retrieved https://books.google.com.bn/books?hl=en\&lr=\&id=go_m4Hf2uPoC\&oi=fnd\&pg=PP1\&ots=mhkwXA_$18 \& \operatorname{sig}=$ CLoEmTsdRV3AJd2VFTosj98rhmk\&redir_esc=y\#v=onepage \&q \&f=false

[35] Ishihara, T. (2009). Perovskite Oxide for Solid Oxide Fuel Cells. (N. P. Bansal, Ed.). Springer Dordrecht Heidelberg London New York.

[36] Torino, N., Henry, P. F., Knee, C. S., Bjørheim, T. S., Rahman, S. M. H., Suard, E., ... Eriksson, S. G. (2017). The influence of cation ordering, oxygen vacancy distribution and proton siting on observed properties in ceramic electrolytes: The case of scandium substituted barium titanate. Dalton Transactions, 46(26), 8387-8398.

[37] team, I. C.-19 health service utilization forecasting, \& Murray, C. J. (2020). Forecasting the impact of the first wave of the COVID-19 pandemic on hospital demand and deaths for the USA and European Economic Area countries. medRxiv, 2020.04.21.20074732.

[38] Nurato, Majlan, E. H., Daud, W. R. W., Husaini, T., Rosli, M. I., Sulong, A. B., \& Sebayang, D. (2019). Finite element analysis for stress distribution in a proton exchange membrane fuel cell stack. International Journal of Integrated Engineering, 11(7), 233-240. 
[39] Ding, H., Tao, Z., Liu, S., \& Yang, Y. (2016). A redox-stable direct-methane solid oxide fuel cell (SOFC) with $\mathrm{Sr} 2 \mathrm{FeNb} 0.2 \mathrm{Mo} 0.8 \mathrm{O} 6-\delta$ double perovskite as anode material. Journal of Power Sources, 327, 573-579.

[40] Shaikh, S. P. S., Muchtar, A., \& Somalu, M. R. (2015, June 20). A review on the selection of anode materials for solid-oxide fuel cells. Renewable and Sustainable Energy Reviews. Elsevier Ltd.

[41] Zheng, K., \& Świerczek, K. (2016). Evaluation of W-containing Sr1 -xBaxFe0.75W0.25O3- $\delta(x=0,0.5,1)$ anode materials for solid oxide fuel cells. Solid State Ionics, 288, 124-129.

[42] Jiang, S. P., \& Chan, S. H. (2004). A review of anode materials development in solid oxide fuel cells. Journal of Materials Science, 39(14), 4405-4439.

[43] Spacil, H. S. (1970). Electrical device including nickel-containing stabilized zirconia electrode.

[44] Fagg, D. P., Mather, G. C., \& Frade, J. R. (2003). Cu-Ce0.8Gd0.2O2- $\delta$ materials as SOFC electrolyte and anode. Ionics, 9(3-4), 214-219.

[45] Costa-Nunes, O., Gorte, R. J., \& Vohs, J. M. (2005). Comparison of the performance of Cu-CeO2-YSZ and NiYSZ composite SOFC anodes with H2, CO, and syngas. Journal of Power Sources, 141(2), 241-249.

[46] Su, P.-C., Chao, C.-C., Shim, J. H., Fasching, R., \& Prinz, F. B. (2008). Solid Oxide Fuel Cell with Corrugated Thin Film Electrolyte. Nano Letters, 8(8), 2289-2292.

[47] Shaula, A. L., Kharton, V. V., \& Marques, F. M. B. (2004). Phase interaction and oxygen transport in $\mathrm{La} 0.8 \mathrm{Sr} 0.2 \mathrm{Fe} 0.8 \mathrm{Co} 0.2 \mathrm{O} 3-(\mathrm{La} 0.9 \mathrm{Sr} 0.1) 0.98 \mathrm{Ga} 0.8 \mathrm{Mg} 0.2 \mathrm{O} 3$ composites. Journal of the European Ceramic Society, 24(9), 2631-2639.

[48] Sacanell, J., Hernández Sánchez, J., Rubio López, A. E., Martinelli, H., Siepe, J., Leyva, A. G., ... Lamas, D. G. (2017). Oxygen Reduction Mechanisms in Nanostructured $\mathrm{La}_{0.8} \mathrm{Sr}_{0.2} \mathrm{MnO}_{3}$ Cathodes for Solid Oxide Fuel Cells. The Journal of Physical Chemistry C, 121(12), 6533-6539.

[49] Mücke, R., Menzler, N. H., Buchkremer, H. P., \& Stöver, D. (2009). Cofiring of thin zirconia films during SOFC manufacturing. In Journal of the American Ceramic Society (Vol. 92).

[50] Garche, J., \& Jörissen, L. (2015). Applications of Fuel Cell Technology: Status and Perspectives. Retrieved from www.electrochem.org

[51] Masiol, M., \& Harrison, R. M. (2014, October 1). Aircraft engine exhaust emissions and other airport-related contributions to ambient air pollution: A review. Atmospheric Environment. Elsevier Ltd.

[52] Elsevier Advanced Technology. (2011). Vaillant unveils wall-mounted CHP unit, using staxera SOFC. Fuel Cells Bulletin (Vol. 2011).

[53] Kupecki, J. (2015). Off-design analysis of a micro-CHP unit with solid oxide fuel cells fed by DME. International Journal of Hydrogen Energy, 40(35), 12009-12022.

[54] Peña, M. A., \& Fierro, J. L. G. (2001). Chemical Structures and Performance of Perovskite Oxides. Chemical Reviews, 101(7), 1981-2018.

[55] Tanaka, H., \& Misono, M. (2001). Advances in designing perovskite catalysts Hirohisa. Current Opinion in Solid State and Materials Science, 5, 381-387.

[56] Cava, R. J., Batlogg, B., Krajewski, J. J., Farrow, R., Rupp, L. W., White, A. E., ... Kometani, T. (1988). Superconductivity near $30 \mathrm{~K}$ without copper: the Ba0.6K0.4BiO3 perovskite. Nature, 332(6167), 814-816.

[57] Afroze, S., Binti Haji Bakar, A. N., Reza, M. S., Salam, M. A., \& Azad, A. K. (2018). Polyvinylidene fluoride (PVDF) piezoelectric energy harvesting from rotary retracting mechanism: imitating forearm motion. In 7 th Brunei International Conference on Engineering and Technology 2018 (BICET 2018) (pp. 94 (4 pp.)-94 (4 pp.)). Institution of Engineering and Technology.

[58] Schlom, D. G., Chen, L.-Q., Pan, X., Schmehl, A., \& Zurbuchen, M. A. (2008). A Thin Film Approach to Engineering Functionality into Oxides. Journal of the American Ceramic Society, 91(8), 2429-2454.

[59] Goldschmidt, V. M. (1926). Die Gesetze der Krystallochemie. Die Naturwissenschaften, 14(21), $477-485$.

[60] Zhou, Q., Xu, L., Guo, Y., Jia, D., Li, Y., \& Wei, W. C. J. (2012). La0.6Sr0.4Fe0.8Cu0.2O3- $\delta$ perovskite oxide as cathode for IT-SOFC. International Journal of Hydrogen Energy, 37(16), 11963-11968.

[61] Natile, M. M., Eger, G., Batocchi, P., Mauvy, F., \& Glisenti, A. (2017). Strontium and copper doped LaCoO3: New cathode materials for solid oxide fuel cells. International Journal of Hydrogen Energy, 42(3), 1724-1735.

[62] Cowin, P. I., Lan, R., Petit, C. T. G., Du, D., Xie, K., Wang, H., \& Tao, S. (2017). Conductivity and redox stability of new perovskite oxides SrFe0.7TM0.2Ti0.1O3- $\delta(\mathrm{TM}=\mathrm{Mn}, \mathrm{Fe}, \mathrm{Co}, \mathrm{Ni}, \mathrm{Cu})$. Solid State Ionics, 301, 99-105.

[63] Gao, L., Zhu, M., Li, Q., Sun, L., Zhao, H., \& Grenier, J. C. (2017). Electrode properties of Cu-doped Bi 0.5 Sr $0.5 \mathrm{FeO} 3-\delta$ cobalt-free perovskite as cathode for intermediate-temperature solid oxide fuel cells. Journal of Alloys and Compounds, 700, 29-36.

[64] Lan, R., Cowin, P. I., Sengodan, S., \& Tao, S. (2016). A perovskite oxide with high conductivities in both air and reducing atmosphere for use as electrode for solid oxide fuel cells. Scientific Reports, 6(1), 31839.

[65] Zhu, C., Liu, X., Xu, D., Yan, D., Wang, D., \& Su, W. (2008). Preparation and performance of Pr0.7Sr0.3Co1 yCuyO3 - $\delta$ as cathode material of IT-SOFCs. Solid State Ionics, 179(27-32), 1470-1473.

[66] Lee, K. T., \& Manthiram, A. (2007). Effect of cation doping on the physical properties and electrochemical performance of $\mathrm{Nd} 0.6 \mathrm{Sr} 0.4 \mathrm{Co} 0.8 \mathrm{M} 0.2 \mathrm{O} 3-\delta(\mathrm{M}=\mathrm{Ti}, \mathrm{Cr}, \mathrm{Mn}, \mathrm{Fe}, \mathrm{Co}$, and $\mathrm{Cu})$ cathodes. Solid State Ionics, 178(13-14), 995-1000.

[67] Yu, H.-C., Zhao, F., Virkar, A. V., \& Fung, K.-Z. (2005). Electrochemical characterization and performance evaluation of intermediate temperature solid oxide fuel cell with $\mathrm{La} 0.75 \mathrm{Sr} 0.25 \mathrm{CuO} 2.5-\delta$ cathode. Journal of Power Sources, 152, 22-26. 
[68] Ling, Y., Zhao, L., Lin, B., Dong, Y., Zhang, X., Meng, G., \& Liu, X. (2010). Investigation of cobalt-free cathode material $\mathrm{Sm} 0.5 \mathrm{Sr} 0.5 \mathrm{Fe} 0.8 \mathrm{Cu} 0.2 \mathrm{O} 3-\delta$ for intermediate temperature solid oxide fuel cell. International Journal of Hydrogen Energy, 35(13), 6905-6910.

[69] Zhao, L., He, B., Zhang, X., Peng, R., Meng, G., \& Liu, X. (2010). Electrochemical performance of novel cobalt-free oxide $\mathrm{Ba} 0.5 \mathrm{Sr} 0.5 \mathrm{Fe} 0.8 \mathrm{Cu} 0.2 \mathrm{O} 3-\delta$ for solid oxide fuel cell cathode. Journal of Power Sources, 195(7), 1859-1861.

[70] Wang, S.-F., Yeh, C.-T., Wang, Y.-R., \& Hsu, Y.-F. (2012). Effects of (LaSr)(CoFeCu)O3- $\delta$ cathodes on the characteristics of intermediate temperature solid oxide fuel cells. Journal of Power Sources, 201, 18-25.

[71] Blum, L. (2017). An Analysis of Contact Problems in Solid Oxide Fuel Cell Stacks Arising from Differences in Thermal Expansion Coefficients. Electrochimica Acta, 223, 100-108.

[72] Singhal, S. C., \& Kendall, K. (2003). High Temperature Solid Oxide Fuel Cells: Fundamentals, Design and Applications. (S. C. Singhal \& K. Kendall, Eds.). Elsevier.

[73] Tanner, C. W. (1997). The Effect of Porous Composite Electrode Structure on Solid Oxide Fuel Cell Performance. Journal of The Electrochemical Society, 144(1), 21.

[74] Fan, L., Wang, C., Chen, M., \& Zhu, B. (2013). Recent development of ceria-based (nano)composite materials for low temperature ceramic fuel cells and electrolyte-free fuel cells. Journal of Power Sources, 234, 154-174.

[75] Batool, R., Gill, R., Altaf, F., Ahmad, M. A., Raza, R., Khan, M. A., .. Abbas, G. (2019). Structural and electrochemical study of $\mathrm{Ba} 0.15 \mathrm{Cu} 0.15 \mathrm{Ni} 0.10 \mathrm{Zn} 0.60$ oxide anode for low temperature solid oxide fuel cell. Journal of Alloys and Compounds, 780, 653-659.

[76] Zhou, Q., Xu, L., Guo, Y., Jia, D., Li, Y., \& Wei, W. C. J. (2012). La0.6Sr0.4Fe0.8Cu0.2O3- $\delta$ perovskite oxide as cathode for IT-SOFC. International Journal of Hydrogen Energy, 37(16), 11963-11968.

[77] Virkar, A. V, Chen, J., Tanner, C. W., \& Kim, J.-W. (2000). The role of electrode microstructure on activation and concentration q polarizations in solid oxide fuel cells. Solid State Ionics (Vol. 131). Retrieved from www.elsevier.com/locate/ssi

[78] Lee, J.-H., Moon, H., Lee, H.-W., Kim, J., Kim, J.-D., \& Yoon, K.-H. (2002). Quantitative analysis of microstructure and its related electrical property of SOFC anode, Ni-YSZ cermet. Solid State Ionics, 148(1-2), $15-26$.

[79] Afroze, S., Torino, N., Henry, P. F., Sumon Reza, M., Cheok, Q., \& Azad, A. K. (2020). Insight of novel layered perovskite PrSrMn2O5+ $\delta$ : A neutron powder diffraction study. Materials Letters, 261, 127126.

[80] Afroze, S., Abdalla, A. M., Radenahmad, N., Hoon Nam, Q. C., \& Azad, A. K. (2018). Synthesis, structural and thermal properties of double perovskite NdSrMn2O6 as potential anode materials for solid oxide fuel cells. In IET Conference Publications (Vol. 2018).

[81] Divisek, J., Jung, R., \& Vinke, I. C. (1999). Structure investigations of SOFC anode cermets Part II Electrochemical and mass transport properties. Journal of applied electrochemistry, 29, 165-170.

[82] Powering field hospitals to save lives during the COVID-19 outbreak | Bloom Energy. (n.d.). Retrieved May 12, 2020, from https://www.bloomenergy.com/blog/powering-field-hospitals-save-lives-during-covid-19-outbreak

[83] Hawkes, A. D., Aguiar, P., Croxford, B., Leach, M. A., Adjiman, C. S., \& Brandon, N. P. (2007). Solid oxide fuel cell micro combined heat and power system operating strategy: Options for provision of residential space and water heating. Journal of Power Sources, 164(1), 260-271.

[84] Hou, M., Sun, W., Li, P., Feng, J., Yang, G., Qiao, J., ... Sun, K. (2014). Investigation into the effect of molybdenum-site substitution on the performance of $\mathrm{Sr} 2 \mathrm{Fe} 1.5 \mathrm{Mo} 0.5 \mathrm{O} 6-\delta$ for intermediate temperature solid oxide fuel cells. Journal of Power Sources, 272, 759-765.

[85] Jaiswal, N., Kumar, D., Upadhyay, S., \& Parkash, O. (2016). High electrical conductivity of nanocomposites based on $\mathrm{Ce} 0.82 \mathrm{Sm} 0.16 \mathrm{Sr} 0.02 \mathrm{O} 1.90$ and $(\mathrm{Li} / \mathrm{Na}) 2 \mathrm{CO} 3$ for low temperature solid oxide fuel cells. Ceramics International, 42(7), 9004-9010.

[86] Matheswaran, P., Rajasekhar, M., \& Subramania, A. (2017). Assisted combustion synthesis and characterization of $\operatorname{Pr} 0.6 \mathrm{Sr} 0.4 \mathrm{MnO} 3 \pm \delta$ nano crystalline powder as cathode material for IT-SOFC. Ceramics International, 43(1), 988-991.

[87] Sood, K., Singh, K., Basu, S., \& Pandey, O. P. (2016). Optical, thermal, electrical and morphological study of La1-xCaxGaO3- $\delta(x=0,0.05,0.10,0.15$ and 0.20$)$ electrolyte. Journal of the European Ceramic Society, 36(13), 3165-3171. 